Tarbawi: Jurnal Ilmu Pendidikan p-ISSN:1858-1080 | e-ISSN: 2615-6547 Vol. 16, No. 1, Juli 2020, 46 - 58

\title{
Pengaruh Model Contextual Teaching and Learning Terhadap Kemampuan Pemecahan Masalah Matematis Berdasarkan Kemandirian Belajar Siswa SMP/MTs
}

\author{
Siti Mamartohiroh, Ramon Muhandaz, Rena Revita \\ Universitas Islam Negeri Siltan Syarif Kasim Riau \\ E-mail: rena.revita@uin-suska.ac.id
}

\begin{abstract}
Abstrak: Penelitian ini bertujuan untuk mengetahui pengaruh penerapan model Contextual Teaching and Learning terhadapKemampuan Pemecahan Masalah Matematis berdasarkan Kemandirian Belajar Siswa SMP/MTs. Jenis penelitian ini merupakan penelitian eksperimen dengan desain Factorial experiment 2x3 dengan Posttest only control group design diakhir. Populasi dalam penelitian ini adalah seluruh siswa kelas VIII MTs GUPPI Bandar Sungai. Teknik pengambilan sampel yang digunakan dalam penelitian ini adalah Cluster Random Sampling, dengan sampel terpilih memiliki kesamaan rata-rata sebelum perlakuan. Teknik pengumpulan data dalam penelitian ini adalah tes, angket, observasi dan dokumentasi. Teknik analisis data menggunakan anova dua arah. Untuk hipotesis 1 diperoleh $F_{A}=5,036>F_{\text {Tabel }}=4,01$ sehingga dapat disimpulkan bahwa terdapat perbedaan kemampuan pemecahan masalah matematis antara siswa yang memperoleh pembelajaran dengan penerapan model Contextual Teaching and Learning dengan siswa yang belajar menggunakan pembelajaran konvensional, dengan skor rata-rata yang lebih baik adalah kelas eksperimen daripada kontrol yaitu berturut-turut adalah 41,94 dan 38,92. Untuk hipotesis 2 diperoleh $F_{B}=4,392>F_{\text {Tabel }}=3,16$ sehingga dapat disimpulkan bahwa terdapat perbedaan kemampuan pemecahan masalah matematis antara siswa yang memiliki kemandirian belajar tinggi, sedang dan rendah, dengan skor rata-rata untuk siswa yang memiliki kemandirian belajar tinggi 43,69 , sedang 38,63 dan rendah 42,83. Untuk hipotesis 3 diperoleh $F_{A \times B}=0,302<F_{\text {tabel }}=$ 3,16 , sehingga dapat disimpulkan bahwa tidak terdapat pengaruhinteraksi antara model pembelajaran dengan kemandirian belajar terhadap kemampuan pemecahan masalah matematis siswa. Penelitian ini dapat dimanfaatkan guru untuk meningkatkan kualitas pembelajaran di kelas terutama dalam meningkatkan kemampuan pemecahan masalah matematis siswa.
\end{abstract}

Katakunci: Model Contextual Teaching and Learning, Kemandirian Belajar, Kemampuan Pemecahan Masalah Matematis

\begin{abstract}
This study aims to determine the effect of applying the contextual teaching and learning model to the mathematical problem solving ability based on the learning independence of junior high school students. This type of research is an experimental research with $2 \times 3$ factorial experiment design with posttest only control group design at the end. The population in this study were all eighth grade students of mts guppi bandar sungai. The sampling technique used in this study was the random sampling cluster, with selected samples having an average similarity before treatment. Data collection techniques in this study were tests, questionnaires, observations and documentation. Data analysis techniques use two-way anova. For bypothesis 1 obtained $f_{-} a=5,036>f_{\text {_tabel }}=4.01$ so it can be concluded that there are differences in mathematical problem solving abilities between students who obtain learning by applying the contextual teaching and learning model with students who learn using conventional learning, with a higher average score good is the experimental class rather than control ie 41.94 and 38.92, respectively. For hypothesis 2 obtained $f_{-} b=4.392>f_{-}$tabel $=3.16$ so it can be concluded that there are differences in mathematical problem solving abilities between students who have high, medium and low learning independence, with an average score for students who have high learning independence 43.69 , was 38.63 and was low 42.83. For bypothesis 3 obtained $f_{-}(a \times b)$ $=0.302<$ ftable $=3.16$, so it can be concluded that there is no interaction effect between the learning model with learning independence on students' mathematical problem solving abilities. This research can be used by teachers to
\end{abstract}


improve the quality of learning in the classroom, especially in improving students' mathematical problem solving abilities.

Keywords: contextual teaching and learning model, learning independence, mathematical problem solving ability

\section{PENDAHULUAN}

Kemampuan pemecahan masalah seyogyanya yang harus dikembangkan pada setiap pembelajaran matematika, karena dalam National Council of Teacher of Mathematics (NCTM) salah satu standar proses dalam pembelajaran matematika yaitu kemampuan pemecahan masalah atau problemsolving (National Council of Teachers of Mathematics, 2000). Hal ini juga tertuang dalam aturan Permendikbud Nomor 21 Tahun 2016 Tentang Standar Isi Pendidikan Dasar dan Menengah yang menetapkan bahwa kompetensi yang harus dicapai oleh siswa pada pelajaran matematika salah satunya adalah menunjukkan sikap logis, kritis, analitis, kreatif, cermat dan teliti, bertanggung jawab, responsif, dan tidak mudah menyerah dalam memecahkan masalah(Kementerian Pendidikan dan Kebudayaan Republik Indonesia, 2016).

Berdasarkan standar isi tujuan pembelajaran matematika pada Permendikbud tersebut, siswa diharapkan memiliki kompetensi untuk tidak mudah menyerah dalam memecahkan masalah matematis dan dapat melakukan kegiatan pemecahan masalah secara rutin,karena dengan seringnya melakukan kegiatan ini, maka siswa akan dapat mengasah dan meningkatkan kemampuan pemecahan masalah matematis. Oleh sebab itu, kemampuan pemecahan masalah dijadikan salah satu tujuan dari pembelajaran matematika.

Namun pada kenyataannya, berdasarkan data-data yang dihimpun oleh peneliti kemampuan menyelesaikan sebuahsoal atau masalah siswa masih tergolong rendah.Hal ini dapat dilihat dari hasil ujian nasional 2019 yang mana soal UN terdiri dari 3 level yaitu pemahaman, aplikasi dan berpikir tingkat tinggi yaitu dengan tingkat capaian rata-rata nilai matematika pada tingkat SMP adalah 46,56 sedangkan pada tingkat MTs 42,24(Pusat Penilaian Pendidikan Kementerian Pendidikan dan Kebudayaan, 2019), sehingga menurut kriteria yang telah ditetapkan BNSP dalam buku saku ujian nasional 2019 nilai rerata dalam rentang $0 \leq$ nilai $\leq 55$ adalah termasuk dalam kriteria kurang(BNSP \& Balitbang Kemdikbud, 2018, hal. 5). Selain itu dari beberapa hasil penelitian yang telah dipublish di jurnal menyimpulkan bahwakemampuan pemecahan masalah matematis siswa masih tergolong rendah pada materi SPLDVtingkat SMP (Suraji et al., 2018), dan pada materi bangun ruang(H. D. Putra et al., 2018). Peneliti juga mendapatkan data hasil prariset yang diberikan kepada siswa di tempat penelitian dengan hasil tes prariset ternyata kemampuan pemecahan masalah masih tergolong rendah.Hal ini ditunjukkan hanya 16\% (sekitar 5 orang) siswa yang mengerjakan dengan benar sesuai dengan indikator. 23\% (sekitar 7 orang) siswa yang 
memahami masalah, 13\% (sekitar 4 orang) siswa yang membuat perencanaan penyelesaian, 64\% (sekitar 20 orang) siswa yang melaksanakan perencanaan dan perhitungan yang tepat, dan hanya 13\% (sekitar 4 orang) siswa yang memeriksa kembali jawaban yang telah mereka dapatkan.Hal itu menggambarkan bahwa kemampuan siswa dalam menyelesaikan masalah matematis masih rendah.

Pada proses pembelajaran terdapat beberapa faktor yang mempengaruhi hasil belajar siswa. Faktor-faktor tersebut diantaranya adalah faktor yang pertama adalah Faktor internal (faktor dari dalam siswa) yang merupakan keadaan/kondisi jasmani dan rohani siswa, kedua Faktor eksternal (faktor dari luar siswa), yang merupakan kondisi lingkungan disekitar siswa(Slameto, 2015), selain dua faktor tersebut juga ada faktor ketiga yaitu Faktor pendekatan pembelajaran, yakni yang intinya adalah upaya / startegi yang diterapkan oleh guru di sekolah(Syah, 2003).

Berdasarkan faktor-faktor yang mempengaruhi hasil belajar tersebut, maka salah satu solusi yang dapat diberikan untuk mengatasi permasalahan tersebut adalah dengan melihat faktor ketiga yaitu faktor pendekatan pembelajaran. Melalui pendekatan pembelajaran, guru dapat menciptakan pembelajaran yang menyenangkan dan bermakna bagi siswa sehingga siswa dapat meningkatkan kemampuan dalam memecahkan masalah matematis.Salah satu tindakan yang dapat dilakukan guru yaitu dengan menerapkan model pembelajaran Contextual Teaching and Learning. Model Contextual Teaching and Learning (CTL) merupakan suatu konsep belajar yang beranggapan bahwa anak akan belajar lebih baik jika lingkungan diciptakan secara alamiah, artinya belajar akan lebih bermakna jika anak bekerja dan mengalami sendiri apa yang dipelajarinya bukan sekedar mengetahuinya(Kunandar, 2007), hal ini berarti pembelajaran tidak hanya kegiatan mentransfer pengetahuan, tetapi siswa mampu memaknai apa yang dipelajari.

Pembelajaran model CTL membantu guru mengaitkan antara materi yang diajarkannya dengan situasi dunia nyata siswa sekaligus mendorong siswa untuk membuat hubungan antara pengetahuan yang dimilikinya dengan penerapannya dalam kehidupan sehari-hari (S. R. Putra, 2013). Hal ini diperkuat dengan hasil penelitian yang telah dilakukan dengan kesimpulan bahwa dengan model CTL kemampuan pemecahan masalah matematis siswalebih lebih baik dari pada kelas konvensional(Laili, 2016; Surya et al., 2016).

Selain model pembelajaran yang merupakan salah satu faktor pendekatan pembelajaran, terdapat faktor lain yang juga mempengaruhi hasil belajar siswa, seperti faktor internal yang berasal dari dalam diri siswa yaitu berupa kemandirian belajar(Amir \& Risnawati, 2015). Kemandirian belajar merupakan suatu aktivitas yang didorong oleh kemauan sendiri, pilihan sendiri, dan tanggung jawab sendiri dari pembelajar(Tirtarahardja \& Sulo, 2005). Dengan adanya kemandirian dalam belajar yang kuat pada diri siswa, dapat menciptakan kualitas kegiatan belajar mengajar menjadi maksimal. 
Berdasarkan uraian tersebut, maka penulis melakukan penelitian yang bertujuan untuk mengetahui pengaruh penerapan model pembelajaran CTL terhadap kemampuan pemecahan masalah matematis berdasarkan kemandirian belajar siswa. Rumusan masalah yang diambil adalahApakah terdapat perbedaan kemampuan pemecahan masalah matematis antara siswa yang memperoleh pembelajaran dengan penerapan model CTL dengan siswa yang memperoleh pembelajaran konvensional?,Apakah terdapat perbedaan kemampuan pemecahan masalah matematis antara siswa yang memiliki kemandirian belajar tinggi, sedang dan rendah?, Apakah terdapat pengaruh interaksi antara model pembelajarandengan kemandirian belajar terhadap pemecahan masalah matematis siswa?.

Berdasarkan rumusan masalah tersebut, maka tujuan penelitian ini adalah untuk mengetahui apakah terdapat perbedaan kemampuan pemecahan masalah matematis antara siswa yang memperoleh pembelajaran dengan penerapan model CTL dengan siswa yang memperoleh pembelajaran konvensional;untuk mengetahui apakah terdapat perbedaan kemampuan pemecahan masalah siswa yang dilihat dari kemandirian belajar siswa yang memiliki kemandirian belajar tinggi, sedang dan rendah; dan untuk mengetahui ada tidaknya pengaruh interaksi antara model pembelajaran dengan kemandirian belajar siswa terhadap kemampuan pemecahan masalah matematis siswa.

\section{METODE}

Tujuan penelitian ini adalah untuk melihat pengaruh suatu penerapan model pembelajaran, maka jenis penelitian ini adalah eksperimen.Bentuk desain eksperimen dalam penelitian ini adalah Factorial Experiment 2x 3.Desain Factorial Eksperiment $2 \times 3$ merupakan modifikasi dari true experiment design Selanjutnya desain faktorial eksperimen merupakan sebuah desain penelitian yang memperhatikan kemungkinan adanya variabel moderator yang mempengaruhi terhadap hasil(Hartono, 2019), sehingga yang menjadi variabel bebas adalah model CTL, variabel terikat adalah kemampuan pemecahan masalah, dan yang menjadi variabel moderator pada penelitian ini adalah kemandirian belajar.Populasi dalam penelitian ini adalah seluruh siswa kelas VIII MTs GUPPI Bandar Sungai yang terdiri dari empat kelas yaitu kelasVIII-A,VIII-B,VIII-C,danVIII-D.Pengambilan sampel menggunakan teknik cluster random sampling. Teknik cluster random ini memilih sampel bukan didasarkan pada individual, tetapi lebih didasarkan pada kelompok, daerah, atau kelompok subjek yang secara alami berkumpul bersama. Dari hasil kemampuan awal sebelum diberinya perlakuan dengan mengambil data nilai UH yang diasumsikan dapat mengukur kesamaan rata-rata sebelum perlakuan karena soal yang sama menghasilkan hasil dari tes menggunakan uji anova satu arah diperoleh keempat kelas tidak terdapat perbedaan yang signifikan sehingga bisa diambil 
cluster/kelas secara acak. Berdasarkan hal tersebut, maka terpilihlah kelas secara acak dengan peluang yang sama yaitu kelasVIII-A dijadikan kelas eksperimendan kelasVIII-B sebagai kelas kontrol. Desain tes yang digunakan dalam penelitian ini adalah posttest-only control group $\operatorname{design}($ Hartono, 2019, hal. 69).

Instrumen yang digunakan dalam penelitian ini adalah tes kemampuan pemecahan masalah matematis, angket kemandirian belajar,serta lembar observasi siswa dan guru. Sebelum memulai penelitian, instrumen tes kemampuan pemecahan masalah matematis terlebih dahulu diuji validitas, reliabilitas, daya pembeda dan tingkat kesukaran dengan hasil dapat dilihat pada Tabel 1.

Tabel 1. Rekap Hasil Uji Coba Soal Kemampuan Pemecahan Masalah

\begin{tabular}{ccccc}
\hline No. Soal & Validitas & Reliabilitas & Daya Beda & Tingkat Kesukaran \\
\hline 1 & Valid & & Cukup & Sedang \\
2 & Valid & & Cukup & Mudah \\
3 & Valid & Sedang & Baik & Sedang \\
4 & Valid & & Baik & Sedang \\
5 & Valid & & Cukup & Sedang \\
6 & Valid & & Cukup & Sedang \\
\hline
\end{tabular}

Sedangkan angket kemandirian belajar siswa terlebih dahulu diuji validitas dan reliabilitas.Uji validitas menggunakan product moment pearson(Hartono, 2015) dengan hasil dari 30 butir angket yang diujikan, terdapat 8 butir angket yang tidak valid,sehingga yang dipakai untuk mengukur kemandirian belajar hanya 22 butir dan memenuhi semua indikator dari kemandirian belajar. Uji reliabilitas menggunakan alpha cronbach(Lestari \& Yudhanegara, 2015)dengan hasil diperoleh $r_{\text {tabel }}=0,3961$ dan oefisien reabilitas $(r)$ yang diperoleh sebesar 0.875 , sehingga dapat disimpulkan menurut kriteria sudah memiliki kualitas yang baik atau tinggi(Lestari \& Yudhanegara, 2015)

Teknik analisis data yang digunakan untuk menguji hipotesis penelitian adalah uji anova dua arah.Angket kemandirian belajar siswa diberikan di awal sebelum perlakuan pada kelas eksperimen dan kelas kontrol.Kemudian, siswa dikelompokkan dalam skala kemandirian belajar dengan siswa kategori tinggi, sedang dan rendah. Kriteria dan hasil pengelompokan kemandirian belajar tersaji pada Tabel 2 (Slameto, 2015).

Tabel 2. Kriteria dan Hasil Penilaian Kemandirian Belajar

\begin{tabular}{|c|c|c|c|}
\hline \multirow{2}{*}{ Kriteria } & \multirow{2}{*}{ Kategori } & \multicolumn{2}{|c|}{ Jumlah siswa } \\
\hline & & Eksperimen & Kontrol \\
\hline$x \geq \bar{x}+\mathrm{SD}$ & Tinggi & 7 Orang & 9 Orang \\
\hline $\bar{x}-\mathrm{SD}<x<\bar{x}+\mathrm{SD}$ & Sedang & 20 Orang & 20 Orang \\
\hline$x \leq \bar{x}-\mathrm{SD}$ & Rendah & 4 Orang & 2Orang \\
\hline Total & & 31 & 31 \\
\hline
\end{tabular}




\section{HASIL}

Sebelum membahas hasil dari uji hipotesis, berikut ini hasil observasi guru dan siswa selama penelitian berlangsung. Gambar 1 menunjukkan tingkat keterlaksanaan setiap pertemuan yang dilakukan oleh guru.

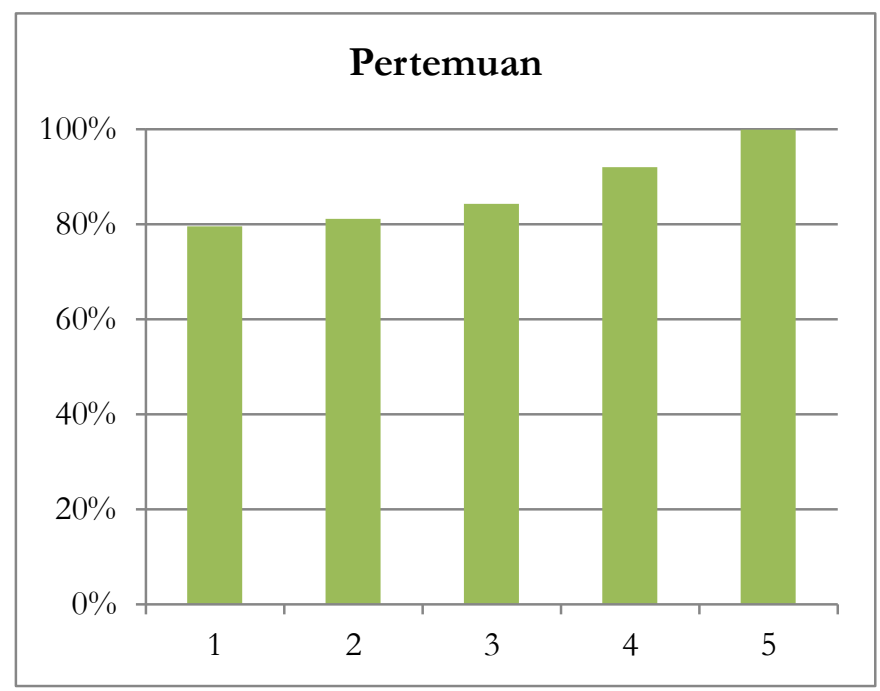

\section{Gambar 1. Grafik Persentase Keterlaksanaan Aktivitas Guru pada Model CTL}

Berdasarkan Gambar 1, dapat kita lihat bahwa keterlaksanaan aktivitas guru terdapat peningkatan disetiap pertemuan.'Tingkat keterlaksanaan setiap pertemuan yang dilakukan oleh siswa dapat dilihat pada Gambar 2.

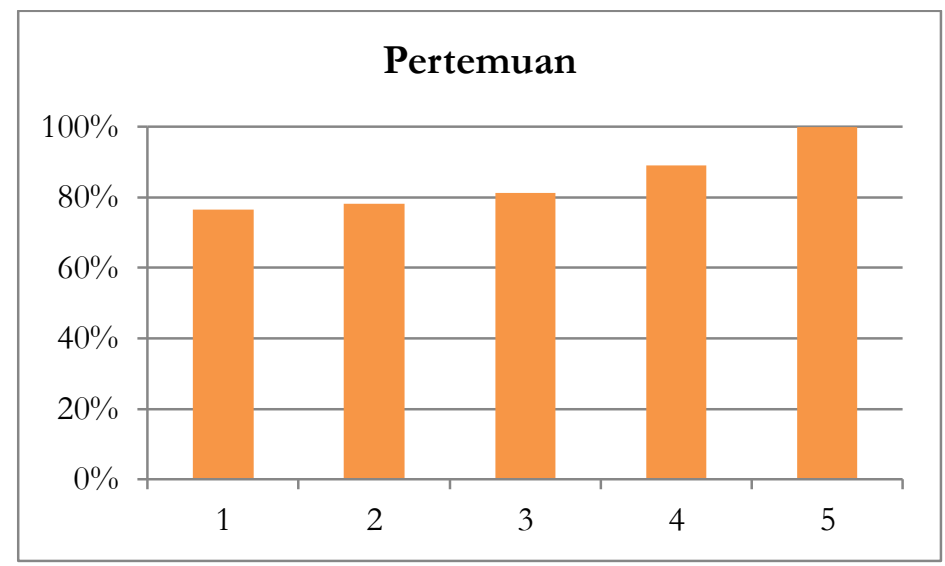

Gambar 2.Grafik Persentase Keterlaksanaan Aktivitas Siswa pada Model CTL

Berdasarkan Gambar 2, keterlaksanan aktivitas siswa juga mengalami peningkatan hingga mencapai $100 \%$. Hal ini menunjukkan bahwa aktivitas siswa dalam proses belajar menggunakan model CTL berjalan sesuai dengan sintak pada CTL tersebut dengan sangat baik, sehingga dibisa dilaksanakan posttes. 
Pertemuan selanjutnya dilaksanakan posttest untuk mengukur kemampuan pemecahan masalah matematis siswa. Berikut disajikan hasil posttest yang dilakukan sebanyak 31 siswa di kelas eksperimen maupun kelas kontrol pada materi relasi dan fungsi yang dapat dilihat pada tabel 3 berikut dan diagram batangnya dapat dilihta pada Gambar 3.

Tabel 3. Hasil Posttest Kelas Eksperimen Dan Kontrol

\begin{tabular}{ccccc}
\hline Kelas & $\overline{\boldsymbol{X}}$ & $\boldsymbol{X}_{\boldsymbol{m a k s}}$ & $\boldsymbol{X}_{\boldsymbol{m i n}}$ & SD \\
\hline Eksperimen & 41,94 & 55 & 28 & 7,27 \\
Kontrol & 38,92 & 49 & 28 & 6,33 \\
\hline
\end{tabular}

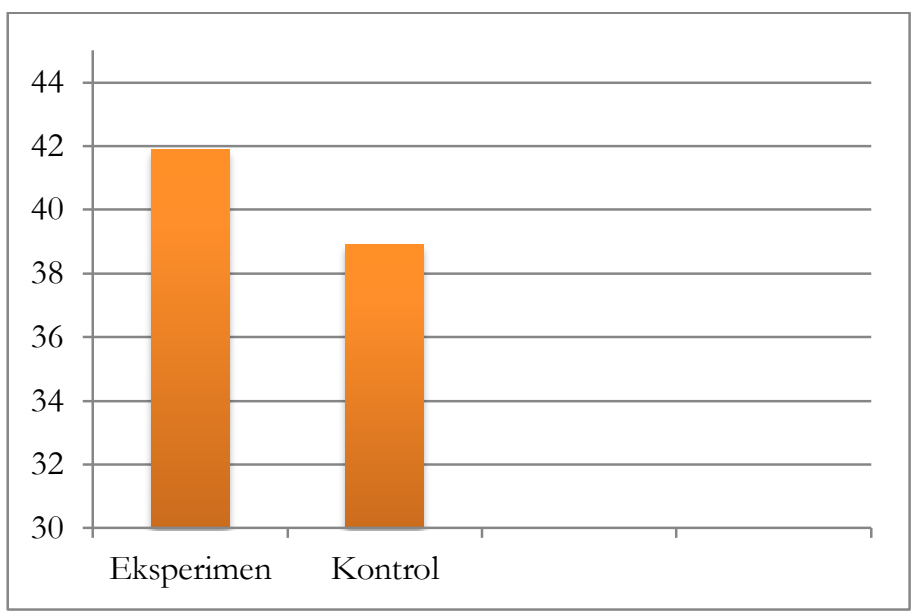

Gambar 3. Perbandingan Rata-rata Posttest Kelas Eksperimen dan Kontrol

Berdasarkan Gambar 3, terlihat bahwa skor rata-rata kelas eksperimen lebih tinggi dibandingkan dengan skor rata-rata kelas kontrol. Untuk memastikan perbedaan dari segi rata-rata kelas secara deskriptif. Selanjutnya dideskripsikan juga hasil tes kemampuan pemecahan masalah berdasarkan kemandirian belajar siswa tinggi, sedang, dan rendah yang dapat dilihat pada tabel 4 berikut ini:

Tabel 4. Hasil Rata-rata Posttest Kemampuan Pecahan Masalah Berdasarkan Kemandirian Belajar

\begin{tabular}{ccc}
\hline Kelompok & $\begin{array}{c}\text { Jumlah siswa } \\
\text { (eksperimen+ } \\
\text { kontrol) }\end{array}$ & Rata-rata $(\overline{\boldsymbol{X}})$ \\
\hline Tinggi & 16 & 43.69 \\
Sedang & 40 & 38.63 \\
Rendah & 6 & 42,83 \\
\hline
\end{tabular}

Berdasarkan Tabel 4, kemampuan pemecahan masalah berdasarkan kemandirian belajar tinggi, sedang dan rendah terlihat secara rata-rata kelompok kemandirian belajar tinggi dengan jumlah siswa 16 orang memperoleh rata-rata 43,69, kelompok sedang dengan jumlah siswa 40 orang mempunyai rata-rata 38,63, dan kelompok rendah dengan jumlah siswa 6 orang mempunyai rata-rata 42,83

Selanjutnya untuk mengetahui ada tidaknya perbedaan yang signifikan dan dapat digeneralisasikan kesimpulannya ke populasi maka akan dilakukan uji inferensial. Sebelumnya 
dilakukan uji normalitas dan homogenitas untuk menentukan uji statistik inferensial yang akan digunakan. Untuk uji normalitas menggunakan rumus chi kuadrat, sedangkan untuk uji homogenitas menggunakan rumus uji $\mathrm{F}$. Hasil dari uji normalitas dan homogenitas posttest antara kedua kelas dapat dilihat pada Tabel 5.

Tabel 5. Hasil Uji Normalitas Posttest

\begin{tabular}{cccc}
\hline Kelas & $X_{\text {hitung }}$ & $X_{\text {tabel }}$ & Kriteria \\
\hline Eksperimen & 6,83 & 11,07 & Normal \\
Kontrol & 7,45 & 11,07 & Normal \\
\hline
\end{tabular}

Berdasarkan Tabel 5, dan pada perhitungan yang telah dilakukan, diketahui bahwa pada kelas eksperimen diperoleh $x_{\text {hitung }}^{2}=6,83$ dan $x_{\text {tabel }}^{2}=11,07$ karena $x_{\text {hitung }}^{2}<x_{\text {tabel }}^{2}$ maka data berdistribusi normal, dan pada kelas kontrol diperoleh $x_{\text {hitung }}^{2}=7,45$ dan $x_{\text {tabel }}^{2}=11,07$ karena $x_{\text {hitung }}^{2}<x_{\text {tabel }}^{2}$ sehingga dapat disimpulkan bahwa pada kelas data juga berdistribusi normal.

Tabel 6. Hasil Uji Homogenitas Posttest

\begin{tabular}{ccccc}
\hline Nilai varians & Eksperimen & Kontrol & $F_{\text {hitung }}$ & $F_{\text {tabel }}$ \\
\hline$S^{2}$ & 51,824 & 31,118 & \multirow{2}{*}{1,66} & \multirow{2}{*}{84} \\
$\mathrm{~N}$ & 31 & 31 & & \\
\hline
\end{tabular}

Berdasarkan Tabel 6, diperoleh $F_{\text {hitung }}=1,66$ dan $F_{\text {tabel }}=1,84$, karena $F_{\text {hitung }}<F_{\text {tabel }}$ maka dapat disimpulkan bahwa kedua varians homogen. Selanjutnya, akan dipaparkan hasil uji hipotesis1,2 dan 3. Karena melibatkan lebih dari dua variabel, maka uji hipotesis dilakukan dengan anova dua arah. Hasil perhitungan terhadap uji anova dua arah dapat dilihat pada Tabel 7.

Tabel 7. Hasil Uji Anova Dua Arah

\begin{tabular}{cccccc}
\hline Varians & Dk & JK & RK & Fh & Fk \\
\hline A & 1 & 191,629 & 191,629 & 5,036 & 4,01 \\
B & 2 & 334,241 & 167,121 & 4,392 & 3,16 \\
(A X B) & 2 & 22,981 & 11,491 & 0,302 & 3,16 \\
\hline
\end{tabular}

Berdasarkan Tabel 7, untuk hipotesis yang pertama, terlihat bahwa $F_{A}=5,036>F_{\text {tabel }}=$ 4,01 itu artinya $H_{0}$ ditolak dan $H_{a}$ diterima yang berarti bahwa terdapat perbedaan kemampuan pemecahan masalah matematis siswa yang belajar menggunakan model pembelajaran Contextual Teaching and Learning dengan siswa yang belajar menggunakan pembelajaran konvensional. Untuk hipotesis kedua,terlihat bahwa $F_{B}=4,392>F_{\text {tabel }}=3,16$. Itu artinya $H_{0}$ ditolak sedangkan $H_{a}$ diterima, sehingga terdapat perbedaan kemampuan pemecahan masalah matematis antara siswa yang Memiliki kemandirian belajar tinggi, sedang dan rendah. Untuk hipotesis ketiga $F_{A \times B}=0,302<$ $F_{\text {tabel }}=3,16$. Itu artinya $H_{0}$ diterima sedangkan $H_{a}$ ditolak, sehingga dapat diartikan bahwa tidak 
terdapat interaksi antara model pembelajaran dan kemandirian belajar terhadap kemampuan pemecahan masalah matematis siswa.

\section{PEMBAHASAN}

Berdasarkan yang telah uraikan pendahuluan sebelumnya bahwa penelitian ini bertujuan untuk melihat pengaruh penerapan model CTL terhadap kemampuan pemecahan masalah matematis berdasarkan kemandirian belajar siswa. Hasil temuan dari analisis data yang dilakukan menunjukkan bahwa untuk hipotesis pertama menyimpulkan bahawa terdapat perbedaan yang signifikan kemampuan pemecahan masalah matematis siswa yang belajar menggunakan model pembelajaran CTL daripada siswa yang belajar menggunakan pembelajaran konvensional. Hal tersebut dapat dibuktikan dari nilai rata-rata kelas yang lebih baik adalah kelas ekperimen yang menggunkan model CTL dibandingankan pada kelas kontrol, perolehan skor rata-rata antara kelas eksperimen dan kontrol berturut-turut 41,94 dan 38,92. Dan dari segi penyebaran data yang dapat dilihat pada tabel 3 sebaran data kelas eksperimen lebih tinggi daripada kelas kontrol artinya adalah distribusi nilai kelas eksperimen lebih luas daripada kelas kontrol, serta jumlah skor maksimum ekperimen dari 6 soal juga lebih tinggi dari pada kelas kontrol masing-masing sebesar 55 dan 49 dengan jumlah skor minimumnya sama-sama 28. Selain itu juga dibuktikan dari beberapa perbandingan lembar jawaban siswa seperti pada Gambar 4.

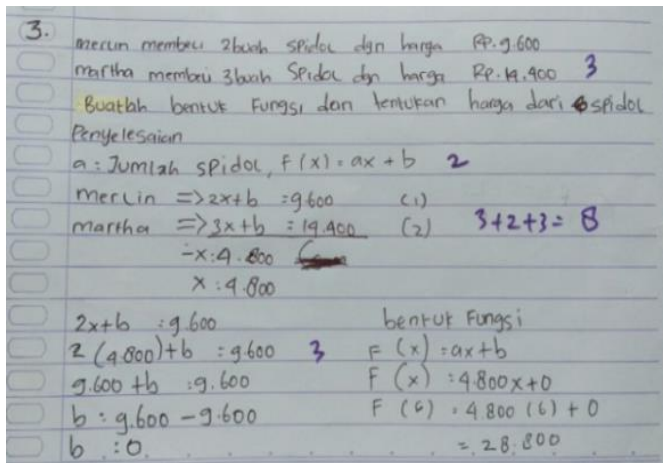

(a)

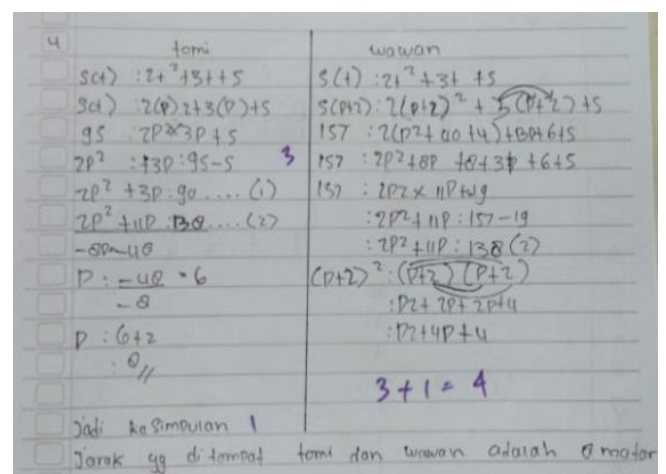

(b)

\section{Gambar 4. Salah Satu Contoh Lembar Jawaban Siswa (a) Kelas Eksperimen (b) Kelas Kontrol}

Berdasarkan gambar 4 tersebut terlihat bahwa siswa pada kelas ekperimen pada indiktor 1 sudah mampu memahami permasalahan dengan baik sehingga mendapakan skor 3, sedangkan pada kelas kontrol siswa belum mampu membuat apa yang diketahui dan apa yang ditanya (memahami masalah pada soal) sehingga tidak memperoleh nilai. Pada indikator 2 siswa kelas eksperimen sudah sebagian besar siswa sudah mampu membuat perencanan untuk menyelesaikan masalah dengan baik, sedangkan pada kelas kontrol banyak yang belum membuat perencanaan 
dengan baik. Pada indikator 3, siwa pada kelas eksperimen sudah banyak menyelesaikan perhitungan dengan baik namun masih ada sebagian kecil yang salah pada perhitungan akhir begitu halnya pada kelas kontrol sudah mulai perhitungan namun banyak melakukan kesalahan-kesalahan. Pada indiktor 4, hanya beberapa dari kelas eksperimen yang mampu untuk memeriksa kebenaran jawaban mereka sedangkan pada kelas kontrol tidak ada. Secara keseluruhan tingkat keberhasilan pada soal no.1 pada kelas ekspeimen 74,19\% sedangkan kontrol 64,52\%. Pada soal no.2 tingkat keberhasilan menjawab soal kelas eksperimen 77,42\% sedangkan kelas kontrol 67,74\%. Pada soal no.3 tingkat keberhasilan menjawab soal kelas eksperimen 70,97\% sedangkan kelas kontrol 61,29\%. Pada soal no.4 tingkat keberhasilan menjawab soal kelas eksperimen 67,74\% sedangkan kelas kontrol 61,29\%. Pada soal no.5 tingkat keberhasilan menjawab soal kelas eksperimen 61,29\% sedangkan kelas kontrol 58,06\%. Pada soal no.6 tingkat keberhasilan menjawab soal kelas eksperimen 70,96\% sedangkan kelas kontrol 41,94\% .

Hasil eksperimen yang dilakukan peneliti beserta bukti-bukti yang telah dipaparkan membuktikan teori oleh Kunandar(2007) yang menyatakan bahwa kemampuan dalam menyelesaikan masalah atau soal akan lebih bermakna apabila anak bekerja dan mengalami sendiri apa yang dipelajarinya yang dalam hal ini sangat pas dengan karakteristik dari model CTL.Dan juga memberi penegasan dari beberapa penelitian sebelumnya pada materi yang berbeda tentang meningkatkan kemampuan pemecahan masalah melalui model CTL.

Hipotesis kedua, berdasarkan perhitungan uji anova dua arah $F_{B}=4,392$ dan $F_{\text {tabel }}=$ 3,16 Berdasarkan perhitungan, diketahui bahwa $F_{\text {hitung }}>t_{\text {tabel }}$ yaitu 4,392 $>3,16$ maka $H_{a}$ diterima dan $H_{0}$ ditolak. Hal ini berarti bahwa terdapat perbedaan kemampuan pemecahan masalah matematis antara siswa yang memiliki kemandirian belajar tinggi, sedang dan rendah, dimana kemampuan pemecahan masalah berdasarkan hasil rata-rata dari tabel 4 menunjukkan bahwa kemapuan pemecahan masalah dengan kemandirian belajar tinggi lebih baik daripada kemampuan pemecahan masalah dengan kemandirian belajar sedang maupun rendah, sedangkan untuk kemampuan pemecahan masalah kemandirian belajar rendah lebih baik daripada kelompok sedang maka rata-ratanya dapat dimodelkan seperti berikut: kelompok sedang < kelompok rendah $<$ kelomok tinggi, dengan masing-masing rata-rata kelompok tinggi 43,69, sedang 38,63 dan rendah 42,83. Berikut juga disajikan beberapa perbandingan lembar jawaban siswa kelompok tinggi,sedang, dan rendah. 

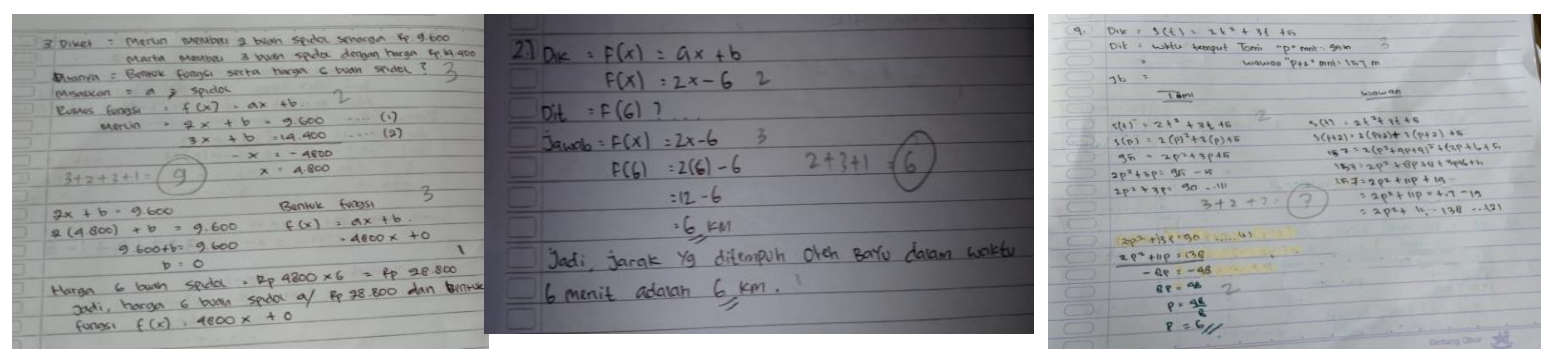

Gambar 5. Perbandingan Lembar Jawaban Siswa Kelompok Tinggi, Sedang, dan Rendah

Berdasarkan Gambar 5, terlihat bahwa lembar jawaban pada kelompok kemandirin belajar tinggi mendapatkan skor 9, sedangkan sedang mendapatkan nilai 6 , serta rendah mendapat skor 7 sehingga ketika ditotal dan dirata-ratakan kemampuan pemecahan masalah dengan kemandirian belajar tinggi lebih baik daripada sedang maupun rendah.

Pada hipotesis ketiga menunjukkan $F(A \times B)_{\text {hitung }}=0,302$ dan $F_{\text {tabel }}=3,16$. Sehingga dapat disimpulkan bahwa $F(A \times B)_{\text {hitung }}<F_{\text {tabelyang }}$ berarti $H_{0}$ diterima dan $H_{a}$ ditolak.Berdasarkan hasil tersebut diperoleh bahwa tidak terdapat pengaruh interaksi kemandirian belajar dengan model pembelajaran dalam meningkatkan kemampuan pemecahan masalah matematis siswa.Hal ini berarti model CTL tidak secara bersama-sama dengan kemandirian belajar dalam mempengaruhi kemampuan pemecahan masalah matematis siswa. Hal ini ditunjukan dari beberapa hasil jawaban siswa yang menunjukan bahwa walaupun memiliki kemandirian belajar rendah tetapi dengan mengikuti pembelajarn CTL tetap ada siswa yang mendapat total skor posttest kemampuan pemecahan yang tinggi. Sebaliknya ada sebagian kecil siswa yang memiliki kemandirian belajar tinggi, tapi mendapatkan skor yang rendah. Maka oleh sebab itu dapat diambil kesimpulan berdasarkan uji anova dan analisis lembar jawaban tidak ada interaksi antara model CTL dengan kemandirian belajar terhadap kemampuan pemecahan masalah siswa.

\section{PENUTUP}

Berdasarkan hasil dan pembahasan maka dapat disimpulkan; (1)Terdapat perbedaan kemampuan pemecahan masalah matematis antara siswa yang menggunakan model CTL dengan siswa yang menggunakan pembelajaran konvensional di MTs GUPPI Bandar Sungai dimana kelas yang lebih baik adalah kelas yang menggunkan model CTL dengan rata-rata 41,94 dibandingkan elas kontrol dengan rata-rata 38,92; (2) Terdapat perbedaan kemampuan pemecahan masalah matematis antara siswa yang memiliki kemandirian belajar tinggi, sedang, rendah di MTsGUPPI Bandar Sungai dengan kelompok tinggi lebih baik daripada kelompok sedang maupun rendah, namun kelompok rendah lebih baik rata-rata skornya daripada rata-rata skor kelompok sedang; (3)tidak terdapat 
pengaruh interaksi model pembelajaran dengan kemandirian belajar siswa terhadap kemampuan pemecahan masalah matematis siswa, dimana masih ada sebagian siswa yang mempunyai kemandirian tinggi memperoleh nilai yang rendah begitu juga sebaliknya.

Berdasarkan aktivitas penelitian yang dilakukan peneliti maka peneliti menyarankan :(1) Hendaknya jika ingin melakukan penelitian pendidikan dengan model CTL, peneliti menyarankan agar bisa menyesuaikan waktu pembelajaran, karena penerapan model ini cukup menggunakan waktu yang lama; (2) Jika pembelajaran ada kegiatan berkelompok, hendaknya selalu ingatkan siswa untuk duduk berkelompok sebelum jam pelajarn dimulai, hal ini bertujuan untuk meminimalisir waktu yang lama

\section{REFERENSI}

Amir, Z., \& Risnawati. (2015). Psikologi Pendidikan. Suska Press.

BNSP, \& Balitbang Kemdikbud. (2018). Buku Saku Ujian Nasional 2019. Puspendik kemdikbud. https://puspendik.kemdikbud.go.id/ujian-nasional-un

Hartono. (2015). Analisis Item Instrumen. Zanafa Publishing.

Hartono. (2019). Metode Penelitian. Zanafa Publishing.

Kementerian Pendidikan dan Kebudayaan Republik Indonesia. (2016). Peraturan Menteri Pendidikan dan Kebudayaan Nomor 21 Tabun 2016 Tentang Standar Isi Pendidikan Dasar dan Menengah.

Kunandar. (2007). Guru profesional: implementasi Kurikulum Tingkat Satuan Pendidikan (KTSP) dan persiapan menghadapi sertifikasi guru. Raja Grafindo Persada.

Laili, H. (2016). Pengaruh Model Pembelajaran Contextual Teaching and Learning (CTL) dalam Meningkatkan Kemampuan Pemecahan Masalah Matematika Siswa MTs Nurul Hakim Kediri Ditinjau dari Segi Gender. PALAPA, 4(2), 34-52. https://doi.org/10.36088/palapa.v4i2.22

Lestari, K. E., \& Yudhanegara, M. R. (2015). Penelitian Pendidikan Matematika. Refika Aditama.

National Council of Teachers of Mathematics. (2000). Principles and standards for school mathematics. [English]. NCTM.

Pusat Penilaian Pendidikan Kementerian Pendidikan dan Kebudayaan. (2019). Laporan Hasil Ujian Nasional.

https://hasilun.puspendik.kemdikbud.go.id/\#2019!smp!capaian_nasional!99\&99\&999!T $\& 03 \& T \& T \& 1 \& ! 1 ! \&$

Putra, H. D., Thahiram, N. F., Ganiati, M., \& Nuryana, D. (2018). Kemampuan Pemecahan Masalah Matematis Siswa SMP pada Materi Bangun Ruang. JIPM (Jumal Ilmiah Pendidikan Matematika), 6(2), 82. https://doi.org/10.25273/jipm.v6i2.2007

Putra, S. R. (2013). Desain Belajar Mengajar Kreatif Berbasis SAINS. Diva Press.

Slameto. (2015). Belajar dan Faktor-Faktor yang Mempengarubinya. Rineka Cipta.

Sujadi, Eko. (2017). Penerapan Pendidikan Karakter Cerdas Format Kelompok Untuk

Meningkatkan Nilai Kejujuran Mahasiswa Bimbingan Konseling Islam (BKI) Institut Agama

Islam Negeri (IAIN) Kerinci. Tarbawi: Jurnal Ilmu Pendidikan, 13(1), 97-108.

Suraji, S., Maimunah, M., \& Saragih, S. (2018). Analisis Kemampuan Pemahaman Konsep Matematis dan Kemampuan Pemecahan Masalah Matematis Siswa SMP pada Materi Sistem Persamaan Linear Dua Variabel (SPLDV). Suska Journal of Mathematics Education, 4(1), 9. https://doi.org/10.24014/sjme.v4i1.5057 
Surya, E., Putri, F. A., \& Mukhtar, M. (2016). Improving Mathematical Problem-Solving Ability And Self-Confidence Of High School Students Through Contextual Learning Model. Journal on Mathematics Education, 8(1). https://doi.org/10.22342/jme.8.1.3324.85-94

Syah, M. (2003). Psikologi belajar. Pt RajaGrafindo Persada.

Tirtarahardja, U., \& Sulo, S. L. L. (2005). Pengantar pendidikan. Rineka Cipta. 